\title{
The use of Toxoplasma gondii tachyzoites produced in HeLa cells adhered to Cytodex 1 microcarriers as antigen in serological assays: an application of microcarrier technology
}

\author{
Pelin Sağlam Metiner • Hüseyin Can (1) - Duygu Ayyıldız Tamiş • \\ Muhammet Karakavuk • Ilgın Kımız Geboloğlu • Sultan Gülçe İz • \\ Esra Atalay Şahar • Aysu Değirmenci Döşkaya • Yüksel Gürüz • \\ Saime İsmet Deliloğlu Gürhan · Mert Döşkaya
}

Received: 30 April 2018/ Accepted: 13 October 2018/Published online: 3 January 2019

(C) Springer Nature B.V. 2019

\begin{abstract}
Toxoplasma gondii can infect nearly all warm-blooded animals, including humans. In the laboratory diagnosis of toxoplasmosis, serological tests have importance in detecting antibody response. Traditionally $T$. gondii tachyzoites grown in vivo are being used as an antigen source in serological assays. Currently, tachyzoites produced in vitro are being tested as an antigen source in order to decrease animal use. Microcarrier technology allowed us to grow anchorage-dependent host cells on microcarrier suspension in short time and approximately 10 times
\end{abstract}

Saime İsmet Deliloğlu Gürhan, Mert Döşkaya were the advisors of the BS student Pelin Sağlam Metiner.

P. Sağlam Metiner · D. Ayyıldız Tamiş ·

I. Kımız Geboloğlu · S. Gülçe İz · S. İ. Deliloğlu Gürhan Department of Bioengineering,

Faculty of Engineering, Ege University, Bornova, İzmir, Turkey

H. Can $(\bowtie)$

Department of Biology, Molecular Biology Section, Faculty of Science, Ege University, Bornova, İzmir, Turkey

e-mail: huseyin.can@ege.edu.tr

M. Karakavuk · E. Atalay Şahar .

A. Değirmenci Döşkaya · Y. Gürüz · M. Döşkaya

Department of Parasitology, Faculty of Medicine, Ege

University, Bornova, İzmir, Turkey more than traditional flask technique. The ability of $T$. gondii tachyzoites to grow in host cells adhered to microcarriers has not been analyzed yet. In this study, we aimed to develop a novel in vitro culture method to produce $T$. gondii tachyzoites abundantly using HeLa cells adhered to Cytodex 1 microcarriers. Initially, the growth of HeLa cells adhered to Cytodex 1 was analyzed using RPMI 1640, DMEM, and EMEM. Next, HeLa cells with a concentration of $1 \times 10^{5}$ cells $/ \mathrm{ml}$ and $2 \times 10^{5}$ cells $/ \mathrm{ml}$ were adhered to Cytodex 1 and grown in spinner flasks. Then, T. gondii tachyzoites were inoculated with $1: 1$ and $2: 1$ cell:tachyzoite ratios to HeLa cells adhered to microcarriers in spinner flaks. During continuous production in spinner flasks, tachyzoites were harvested at the 2nd, 4th, and 7th day of culture and the quality of antigens produced from these tachyzoites were tested in ELISA and Western Blotting using sera of patients with toxoplasmosis. The optimization studies showed that finest HeLa inoculation value was $2 \times 10^{5}$ cells $/ \mathrm{ml}$ using RPMI 1640, and the cell:tachyzoite ratio to obtain the highest tachyzoite yield $\left(17.1 \times 10^{7}\right)$ was 1:1 at the 4th day of inoculation. According to the results of ELISA comparing HeLa cell and mouse derived antigens, the highest correlation with mouse antigen was achieved at the 4th day of HeLa cell culture with $1: 1 \mathrm{HeLa}$ :tachyzoite ratio $(P<0.0001)$. The sensitivity and specificity ratios of ELISA were $100 \%$. In addition, Western blotting banding patterns 
of the antigen derived at the 4th day of HeLa cell culture with 1:1 HeLa:tachyzoite ratio was comparable with mouse derived antigen. Overall, this novel methodology can be an alternative source of antigen in diagnostic assays, decrease animal use for antigen production, and contribute to the solution of ethical and economic problems.

Keywords Toxoplasma gondii $\cdot$ HeLa cell · Microcarriers · Antigen

\section{Introduction}

Toxoplasmosis is an infection caused by Toxoplasma gondii which can infect nearly all warm-blooded animals, including humans. Humans and other hosts become infected by consuming food or drink contaminated with sporulated oocysts of $T$. gondii or by ingesting undercooked or raw meat containing tissue cysts of T. gondii (Toulah et al. 2011; Fritz et al. 2012).

Toxoplasmosis in adults with normal immune function is generally asymptomatic however it can lead to a wide range of clinical manifestations in fetus and immune-compromised patients, such as those with acquired immuno-deficiency syndrome, immunosuppressed cancer patients and transplant recipients (Koethe et al. 2015; Masatani et al. 2016).

Serological diagnosis of toxoplasmosis depends mainly on ELISA and IFA since antibody response against $T$. gondii remains positive lifelong. In these assays, T. gondii tachyzoites produced in vivo or in vitro are used as antigen source. In addition, recombinant proteins can also be used as antigen for ELISA (Döşkaya et al. 2014). Antigen production in animal models is problematic due to ethical problems and infrastructural deficiencies such as lack of experienced personnel and standardized vivarium (Değirmenci et al. 2011). On the other hand, in vitro tachyzoite production is easy, cheap and does not cause ethical problems (Ashburn et al. 2000; Chatterton et al. 2002; Buddhirongawatr et al. 2006; Döşkaya et al. 2006). To date, several types of host cells [such as human larynx carcinoma cells (Hep2), Madin Darby bovine kidney cells (MDBK), African green monkey kidney cells (Vero) and human cervical carcinoma cells (HeLa)] have been successfully used to produce T. gondii tachyzoites (Döşkaya et al. 2006;
Diab and El-Bahy 2008; Wu et al. 2011). Among them HeLa cells were frequently used due to the abundant production of $T$. gondii tachyzoites and less host cell contamination (Evans et al. 1999; Ashburn et al. 2000, 2001; Chatterton et al. 2002; Ho-Yen 2010; Döşkaya et al. 2006; Değirmenci et al. 2011). Conversely, baby hamster kidney cells (BHK), rabbit kidney cells (RK13), human rhabdomyosarcoma cells (RDA), chicken embryo related cells (CER) and Lewis lung carcinoma cells (LLC) are not found suitable enough for in vitro tachyzoite production (Evans et al. 1999; Diab and El-Bahy 2008). Cell culture derived tachyzoites are being used in biological analysis, drug or vaccine development studies, and as a source of antigen for serological assays.

Cell cultures are systems in which cells are grown in controlled conditions in vitro. Thanks to the cell cultures, host cell-pathogen relations can be examined vigorously using plenty of techniques. Also, cell culture techniques are vital for the production of many important biological materials such as antigen for vaccine and diagnostic assays, enzymes, hormone, antibody, and cytokines (Butler 2005; Freshney 2010; Oyeleye et al. 2016). In cell culture, cells are divided into monolayer cells and suspended cells according to their origin. Monolayer cells (adherent, anchoragedependent cell types) are surface dependent to grow and survive. Suspended cells are suspended in the cell medium independent of the surface (Freshney 2010; Oyeleye et al. 2016).

Microcarrier technology is being used to grow various anchorage-dependent cell types which are not able to grow in a suspension. This approach has been introduced firstly by van Wezel in 1967 (van Wezel 1967; Kato et al. 2003; Microcarrier Cell Culture Prenciples \& Methods 2005; Sun et al. 2011; Chen et al. 2013; Jakob et al. 2016). Through the use of this technology, host cells can be grown easily approximately 10 times more than traditional flask technique (Kato et al. 2003; Chen et al. 2013). The ability of $T$. gondii tachyzoites to be grown in host cells adhered to microcarriers has not been analysed yet. Using this approach, T. gondii tachyzoites can be produced abundantly in a short time.

Moreover, other advantages of microcarriers are; (1) Surface-volume ratio can be enhanced by changing microcarrier concentration. For example; when $3 \mathrm{mg} /$ ml Cytodex 1 is used, surface volume for adherent cells become approximately $1.32 \times 10^{4} \mathrm{~cm}^{2} / 1$ which 
is equal to $176 \mathrm{~T}$-flasks with $75 \mathrm{~cm}^{2}$ surface area (2) The use of a homogeneously stirred suspension enables to monitor and control of various parameters such as $\mathrm{pH}, \mathrm{pO}_{2}$, and concentration of medium components which results with more optimal and reproducible cell cultures (3) In addition, scale-up can be easily performed by bioreactors (Kato et al. 2003; Wu et al. 2004; Microcarrier Cell Culture Prenciples $\&$ Methods 2005; Chen et al. 2013).

There are two types of microcarriers; one of them is the positively charged carrier [such as dextran-based Cytodex 1, (GE Healthcare), collagen or ECM-coated dextran-based Cytodex 3 (GE Healthcare) or polystyrene-based HyQspheres Pro-F 102-4 (Thermo Scientific)] or non-charged carriers [such as like HyQspheres P 102-4 or macro-porous carriers based on gelatine (Cultisphere, Percell Biolytica) or cellulose (Cytopore, GE Healthcare)] (Merten, 2015).

In the present study, we aimed to develop a novel in vitro culture method to produce $T$. gondii tachyzoites abundantly in HeLa cells adhered to Cytodex 1 microcarriers, which can be used as an antigen source in serological assays. Cytodex 1 microcarriers have been used to grow HeLa cells because these carriers support cell growth by their positively charged diethylaminoethyl (DEAE) groups (Rourou et al. 2007). In addition, Boudreault et al. (2001) have showed that the use of Cytodex 1 microcarriers is suitable for scale up of HeLa cells.

To achieve this aim, the growth kinetic and cell adhesion time of HeLa cells adhered to Cytodex 1 were analysed comparatively using three different media (RPMI 1640, DMEM, and EMEM). Next, two different concentrations of HeLa cells $\left(1 \times 10^{5}\right.$ cells/ $\mathrm{ml}$ and $2 \times 10^{5}$ cells $/ \mathrm{ml}$ ) adhered to Cytodex 1 were grown with the selected medium in spinner flasks. After optimization of the growth of HeLa cells on Cytodex 1 in spinner flasks, $T$. gondii tachyzoites were inoculated to the HeLa cells adhered to microcarriers with 1:1 and 2:1 cell:tachyzoite ratios. During continuous production in spinner flasks, tachyzoites were harvested at the 2nd, 4th, and 7th day of culture and used as antigen in ELISA and Western blotting. In the serological assays, antigens derived from microcarrier adherent cells were compared to antigen obtained from mice using well grouped patient sera with toxoplasmosis.

\section{Materials and methods}

Parasite

T. gondii Ankara strain tachyzoites produced in Swiss Webster outbred mice were used in this study as previously described (Döşkaya et al. 2006; Değirmenci et al. 2011; Döşkaya et al. 2013). Briefly, 8-10 weeks old mice were inoculated with $1 \times 10^{5}$ tachyzoites intraperitoneally. After 3-4 days, the peritoneal cavity was washed with sterile $0.9 \% \mathrm{NaCl}$ and the presence of tachyzoites was observed under phase contrast microscopy. Then, the mouse derived tachyzoites were washed three times with $10 \mathrm{ml}$ of phosphate buffer saline (PBS; pH 7.4) and inoculated to HeLa cells or used as antigen. All experiments were performed under the instructions and approval of the Institutional Animal Care and Use Committee (IACUC) of Ege University for animal ethical norms (Permit number: 2014-016). Animals were housed under standard and suitable conditions.

HeLa cell culture in T-flasks

HeLa cells (human cervical carcinoma cells) provided from The Animal Cell Culture Collection (HUKUK, SAP Institute, Ankara, Turkey) were individually grown in three different media (RPMI 1640, DMEM and EMEM) containing $2 \mathrm{~g} / \mathrm{l} \mathrm{NaHCO}_{3}, 10 \mathrm{mM}$ HEPES solution, $2 \mathrm{mM}$-glutamine, $10 \%$ fetal bovine serum (FBS), penicillin $(10 \mathrm{U} / \mathrm{ml})$, streptomycin $(10 \mu \mathrm{g} / \mathrm{ml})$, and gentamycin $(2 \mu \mathrm{g} / \mathrm{ml})$ at $37{ }^{\circ} \mathrm{C}$ in a $5 \% \mathrm{CO}_{2}$ atmosphere. These media are mentioned as growth medium in following sections.

As the monolayer formed, HeLa cells in T-flasks were washed with $\mathrm{Ca}^{2+}$ and $\mathrm{Mg}^{2+}$ free PBS and incubated with $0.25 \%$ trypsin for $5 \mathrm{~min}$ at $37{ }^{\circ} \mathrm{C}$ to release the cells from the flask surfaces. The cells were counted with a haemocytometer and viability was determined by dye exclusion method with $0.4 \%$ trypan blue dye (Applichem, Germany). HeLa cells were subcultured every 3-4 days (Değirmenci et al. 2011). Unless noted otherwise, the entire cell culture media were obtained from Biochrom, Germany. 
Growth kinetics and cell adhesion tests of HeLa cells

The growth kinetic was determined with batch culture mode in a 6-well plate (Greiner, Germany) according to the previously described protocols (Freshney 2010; Kahraman et al. 2013). Briefly, HeLa cells were daily trypsinized from one well and the viability was determined with dye exclusion method. In order to calculate the ratio of live non-adhered cells, cell adhesion assay was performed in a 6-well plate (Greiner, Germany). Non-adherent HeLa cells were collected from cell medium every $30 \mathrm{~min}$ for $5 \mathrm{~h}$ and counted after staining with $0.4 \%$ trypan blue dye. Also, percent cell viability value was determined by MTT (methyl thiazol tetrazolium) assay in a 96-well plate according to the manufacturer's protocol (MTT, Sigma, ABD).

Preparation of Cytodex 1 microcarriers and adhesion test for HeLa cell

After determining the growth parameters of the HeLa cells in culture dishes, the growth optimization of HeLa cells on Cytodex 1 was performed as described previously (Gürhan et al. 1994; Microcarrier Cell Culture Principles and Methods 2005; Ayyildiz-Tamis et al. 2014). Briefly, the microcarriers were added to a bottle in which the inner surface was covered with a non-toxic silicone cream (Merck, Germany), to prevent the adhesion of microcarriers to bottle surface. Cytodex 1 was conditioned with PBS for $3 \mathrm{~h}$ and thereafter, washed three times with PBS, sterilized by autoclave at $115^{\circ} \mathrm{C}$ for $20 \mathrm{~min}$, and kept at $+4{ }^{\circ} \mathrm{C}$ until use.

In order to adhere cells to microcarriers, $3 \mathrm{~g} / \mathrm{l}$ of Cytodex 1 were incubated with $1 \times 10^{5} \mathrm{cell} / \mathrm{ml} \mathrm{HeLa}$ cells in 6-well plates with RPMI 1640, DMEM and EMEM media individually at $37{ }^{\circ} \mathrm{C}$ in a $5 \% \mathrm{CO}_{2}$ atmosphere. To determine the percent adhesion, nonadhered HeLa cells were collected from each medium every $30 \mathrm{~min}$ and counted after staining with $0.4 \%$ trypan blue dye using a haemocytometer (AyyildizTamis et al. 2014).
HeLa cell culture on Cytodex 1 microcarriers in single-use Erlenmeyer flask

Initially, single-use $30 \mathrm{ml}$ Erlenmeyer flasks (Sartorius Stedim, Germany) were prepared by covering the inner surface with non-toxic silicone cream (Merck, Germany). Thereafter, $3 \mathrm{~g} / \mathrm{l}$ of microcarriers were incubated with $1 \times 10^{5}$ cell $/ \mathrm{ml} \mathrm{HeLa} \mathrm{cells} \mathrm{in} 10 \mathrm{ml}$ of RPMI 1640, DMEM and EMEM media individually at $37{ }^{\circ} \mathrm{C}$ in a $5 \% \mathrm{CO}_{2}$ atmosphere with gentle rotation at $60 \mathrm{rpm}$. As the cells were adhered to Cytodex 1, an additional $10 \mathrm{ml}$ of medium was added to the Erlenmeyer flasks. At the second day of culture, total volume was completed to $30 \mathrm{ml}$ by adding $10 \mathrm{ml}$ of growth medium separately. Cell growth and $\mathrm{pH}$ in the culture were examined daily by light microscopy and $\mathrm{pH}$ meter (Inolab, Germany). As the adherence of HeLa cells reached the highest density, scanning electron microscopy (SEM) was performed. The ideal growth medium to produce HeLa cells in Cytodex 1 was determined based on the results of above described assays and SEM.

HeLa cell culture on Cytodex 1 microcarriers in spinner flask

Approximately $70 \mathrm{ml}$ sized spinner flasks with $50 \mathrm{ml}$ working volume were prepared as described in previous sections. In this set of experiments, initially $3 \mathrm{~g} / \mathrm{l}$ of Cytodex 1 were incubated with $1 \times 10^{5}$ cell/ $\mathrm{ml}$ or $2 \times 10^{5}$ cells $/ \mathrm{ml} \mathrm{HeLa} \mathrm{cells} \mathrm{in} 20 \mathrm{ml}$ selected growth medium at $37{ }^{\circ} \mathrm{C}$ in a $5 \% \mathrm{CO}_{2}$ atmosphere with gentle rotation at $60 \mathrm{rpm}$. As the cells were adhered to the microcarriers, an additional $10 \mathrm{ml}$ of growth medium was added to the spinner flasks. At the second day of culture, total volume was completed to $50 \mathrm{ml}$ by adding $20 \mathrm{ml}$ of growth medium. Cell suspension was examined by light microscopy and as the growth of the cells reached the highest density, scanning electron microscopy (SEM) was performed. The ideal initial cell concentration with the highest confluency on microcarriers was determined based on the results of above described assays and SEM.

Inoculation of $T$. gondii tachyzoites to HeLa cells in spinner flask

T. gondii Ankara strain tachyzoites obtained from mouse peritoneum as described in "Parasite"section 
were used in this set of experiments. Initially, two $250 \mathrm{ml}$ spinner flasks (Corning) with $200 \mathrm{ml}$ working volume, containing HeLa cells growing on Cytodex 1 microcarriers were prepared as described in the "HeLa cell culture on Cytodex 1 microcarriers in spinner flask" section. As the HeLa cells reached $80-90 \%$ confluency on Cytodex 1, the medium was changed with $200 \mathrm{ml}$ of maintenance medium containing $2 \%$ fetal bovine serum (FBS), $2 \mathrm{~g} / \mathrm{l} \mathrm{NaHCO}, 10 \mathrm{mM}$ HEPES solution, $2 \mathrm{mM}$ L-glutamine, penicillin (10 $\mathrm{U} / \mathrm{ml})$, streptomycin $(10 \mu \mathrm{g} / \mathrm{ml})$, gentamycin $(2 \mu \mathrm{g} /$ $\mathrm{ml})$, and Amphotericin B $(1 \mu \mathrm{g} / \mathrm{ml})$, and incubated at $37{ }^{\circ} \mathrm{C}$ in a $5 \% \mathrm{CO}_{2}$ atmosphere for $16 \mathrm{~h}$. The amount of HeLa cells were counted in each experiment by trypsinizing a part of the microcarrier suspension and then counting them by hemocytometer after staining with $0.4 \%$ trypan blue dye.

Thereafter, $100 \mathrm{ml}$ of maintenance medium were discarded and viable $T$. gondii tachyzoites counted with $0.4 \%$ trypan blue dye using hemocytometer were inoculated into spinner flasks. Accordingly, one flask contained equal amount of HeLa cell and tachyzoites (i.e. 1:1 cell:tachyzoite ratio) and the other flask contained the same amount of HeLa cell but half the amount of tachyzoites (i.e. 2:1 cell:tachyzoite ratio). Next, the total volume was completed to $200 \mathrm{ml}$ by maintenance medium and culture was incubated at $37{ }^{\circ} \mathrm{C}$ in a $5 \% \quad \mathrm{CO}_{2}$ atmosphere for 7 days. Cell viability and the presence of tachyzoite in cell suspension were routinely examined by light microscopy.

Approximately $150 \mathrm{ml}$ of cell culture supernatants were collected after the $2 \mathrm{nd}$, 4th, and 7th days of continuous culture from two different flasks with 1:1 and 2:1 HeLa:tachyzoite ratio comprising six groups of antigens. The amount of viable tachyzoites and HeLa cell ingredient were determined with $0.4 \%$ trypan blue dye using hemocytometer.

\section{Serological assays}

The quality of the six antigens obtained from anchorage-dependent HeLa cell culture was compared with antigen derived from Swiss Webster outbred mice using enzyme linked immunosorbent assay (ELISA) and Western blotting. To evaluate the quality of antigens, a cohort of 35 seropositive and 8 seronegative sera (previously tested for anti-Toxoplasma IgG antibodies using ELISA) were used during in house ELISA (Değirmenci et al. 2011; Liang et al. 2011;
Döşkaya et al. 2014). In addition, to compare the banding patterns, 5 seropositive and 5 seronegative samples selected from the above cohort were used in Western blotting. The study was approved by the Research Ethics Committee of the Ege University Faculty of Medicine (Approval number: 14-2.1/9).

Lysate antigens that will be used in ELISA and Western blot was prepared as previously described (Payne et al. 1987; Francis et al. 1988; Gürüz et al. 1996; Değirmenci et al. 2011), Briefly, T. gondii Ankara strain tachyzoites obtained from HeLa cell culture supernatants and Swiss Webster outbred mice intraperitoneal cavity were initially centrifuged at $500 \mathrm{rpm}$ for $10 \mathrm{~min}$ to separate HeLa or mouse cells. After centrifugation, the supernatants containing the tachyzoites were collected, centrifuged for $10 \mathrm{~min}$ at $3000 \times g$ and washed 3 times with PBS (pH 7.4). After removing the supernatant, pellets containing tachyzoites were suspended in $1 \mathrm{ml}$ PBS, counted with a hemocytometer, and then centrifuged at $14.000 \times g$ for $15 \mathrm{~min}$. After centrifugation, supernatants were discarded and the pellets were resuspended in distilled water followed by several cycles of freezing and thawing. Then, the suspensions were centrifuged again at $14.000 \times g$ for $15 \mathrm{~min}$ and supernatants were passed through $0.22 \mu \mathrm{m}$ filter (Sartorius Stedim, Germany) and used as antigen in ELISA and Western blotting.

\section{Enzyme linked immunosorbent assay}

An in house ELISA detecting anti-Toxoplasma IgG antibody was used to compare the 6 different antigens derived from HeLa cells with antigen derived from mouse as previously described with some modifications (Payne et al. 1987; Francis et al. 1988; Değirmenci et al. 2011; Liang et al. 2011). Briefly, each well of the flat bottom microtitre plates (Nunc, USA) was coated with $100 \mu \mathrm{l}$ antigen suspension containing $5.7 \times 10^{5}$ tachyzoites $/ \mathrm{ml}$ and incubated for $1.5 \mathrm{~h}$ at room temperature. Next, the human sera at dilution of $1: 256$ in $5 \%$ nonfat dry milk prepared in $0.05 \%$ PBS-T [PBS containing $0.05 \%$ Tween-20, ( $\mathrm{pH} 7.4)$ ] were added to each well in duplicate, incubated for $30 \mathrm{~min}$ at room temperature and washed three times with $200 \mu \mathrm{l}$ of PBS-T. Then, the wells were probed with anti-Human IgG antibody conjugated with peroxidase (Sigma, Germany) at a dilution of 1:1375 for $30 \mathrm{~min}$ at room temperature. Thereafter, bound antibodies were 
visualized by adding $3,3^{\prime}, 5,5^{\prime}$ tetramethylbenzidine (TMB) substrate. Reaction was stopped by adding $75 \mu \mathrm{l}$ of $2 \mathrm{~N}$ sulfuric acid and the results were evaluated in a micro titer plate reader (Bio-Tek ELx808, U.S.A.) at $450 \mathrm{~nm}$. Samples were considered positive when the absorbance value (AV) of the sera exceeded the mean AV + S.D. of the negative control sera.

Sodium dodecyl sulphate-polyacrylamide gel electrophoresis and Western blotting

The quality of 6 different antigens derived from HeLa cells produced in spinner flasks were compared with antigen derived from mouse using Western blotting as previously described (Değirmenci et al. 2011). To compare the banding patterns of antigens, $5.7 \times 10^{5}$ tachyzoites were separated by sodium dodecyl sulphate-polyacrylamide electrophoresis (SDS-PAGE) using $12 \%$ acrylamide in separating gel. The separated antigens were transferred to a polyvinylidene difluoride (PVDF) transfer membrane (Immobilon- $\mathrm{P}$, Millipore, U.S.A.) and blocked by $6.25 \%$ non-fat dry milk prepared in $1 \times$ TBS-T buffer (Tris buffered saline containing Tween 20; $20 \mathrm{mM}$ Tris- $\mathrm{Cl} \mathrm{pH} 7.8$, $0.5 \mathrm{M} \mathrm{NaCl}, 0.5 \%$ Tween 20) for $30 \mathrm{~min}$ at room temperature. The membranes containing equal numbers of tachyzoites were probed with a 1:100 dilution of positive and negative sera pools in $1 \times$ TBS-T for $90 \mathrm{~min}$ at room temperature. Next, the membranes were washed three times with $1 \times$ TBS-T and probed with a 1:2500 dilution of anti-human IgG antibody conjugated with alkaline phosphatase (Sigma, Germany) in $1 \times$ TBS-T for $60 \mathrm{~min}$ at room temperature. Thereafter, the membranes were washed three times with $1 \times$ TBS-T and the blot was developed with 5-bromo-4-chloro-3-indolyl phosphate (BCIP) and Nitro-BT (Applichem, Germany) diluted in diethanolamine buffer [10\% dietanolamin, $0.5 \mathrm{mM} \mathrm{MgCl} 2$.6$\mathrm{H}_{2} \mathrm{O}, 70 \%$ (v/v) $\left.\mathrm{pH} 9.8\right]$.

\section{Statistical analysis}

The data obtained from this study were processed using Prism 3.03 (GraphPad, San Diego, CA). A twotailed unpaired t test with $95 \%$ confidence interval was used to compare the results of the assays. The HeLa cell culture optimization experiments were performed at least three times and statistical significance was mentioned when the $P$ value was $<0.05$. The correlation between HeLa cell culture and Swiss Webster outbred mice derived antigen absorbance values were evaluated by Pearson correlation and Lineer regression analyses. In addition, the sensitivity and specificity of ELISAs using HeLa cell culture and mouse derived antigens were calculated.

\section{Results}

Growth kinetic of HeLa cells

Growth kinetic of anchorage-dependent HeLa cells were obtained from the set of experiments performed under "HeLa cell culture in T-flasks, Growth kinetics and cell adhesion tests of HeLa cells" sections. According to the results, after a lag phase of 1-2 days HeLa cells incubated with RPMI 1640 entered exponential phase and showed $100 \%$ of confluency at the 5 th day of culture.

In addition, cell concentration was the highest at the 7th day of culture (Fig. 1a). After 7 days, the amount of dead cells increased. Similar results were obtained from HeLa cells incubated with DMEM but stationary phase of HeLa cells was longer (Fig. 1a). In HeLa cells incubated with EMEM, exponential phase was detected at the 8th day of culture following a lag phase which took 1-2 days and the cell amount per ml was the highest (Fig. 1a). Based on these results, although cell viability percentages were similar in all three media during growth period, HeLa cells incubated with RPMI 1640 had the highest viable cell concentration in exponential phase (Fig. 1b).

\section{Cell adhesion test of HeLa cells}

According to the cell adhesion test result, adhesion value percentage was the highest in HeLa cells incubated with RPMI 1640 when compared with other media. Optimal adhesion time of HeLa cells was approximately $180 \mathrm{~min}$ for each medium (Fig. 2a).

MTT assay was performed at the 24th hour of HeLa cell culture and the results showed that the highest HeLa cell yield was detected in RPMI 1640 medium (Fig. 2b).

The growth kinetic, cell adhesion, and MTT assay results demonstrated that anchorage-dependent HeLa 

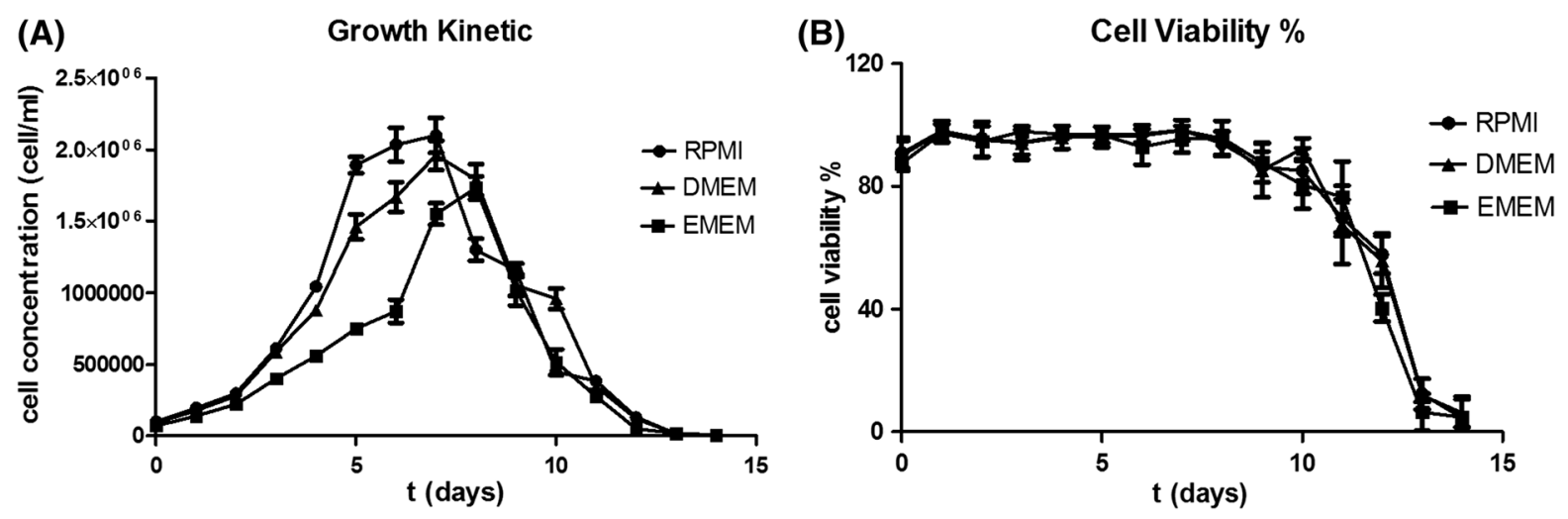

Fig. 1 a Growth kinetics and b cell viability percentage of HeLa cells incubated in RPMI 1640, EMEM and DMEM media
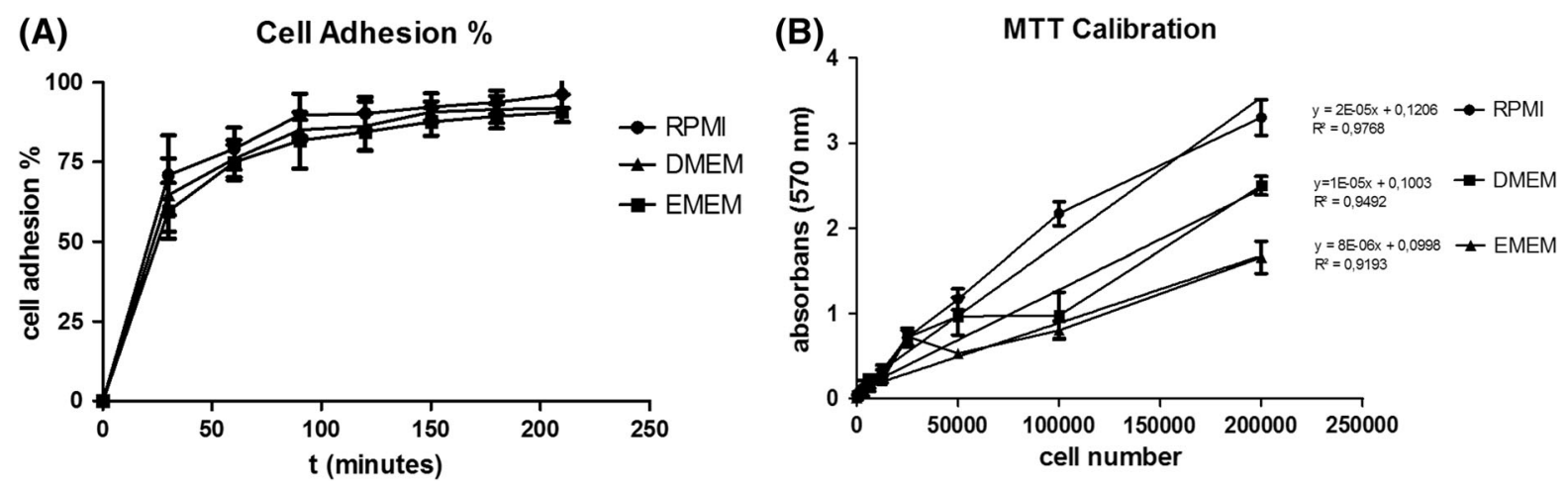

Fig. 2 a Cell adhesion time and b MTT assay results of HeLa cells incubated in RPMI 1640, EMEM and DMEM media

cells can be grown efficiently in RPMI 1640 (Figs. 1, 2).

Cell adhesion test of HeLa cells on Cytodex 1 microcarriers

Adhesion of HeLa cells on microcarriers was completed in $5 \mathrm{~h}$ using three different media. Among them, the adhesion ratio percentage of HeLa cells incubated with RPMI 1640 medium reached up to about $85 \%$. The minimum adhesion was observed in HeLa cells incubated with EMEM medium (Fig. 3).

HeLa cell culture in single-use Erlenmeyer flasks

Decrement in the $\mathrm{pH}$ of the growth medium usually indicates metabolic activity and cell proliferation in cultures (Freshney 2010). Direct observation and calculation of the cell proliferation in the cultures with microcarriers is not easy. To support the light microscopy and SEM imaging, daily $\mathrm{pH}$ controls were

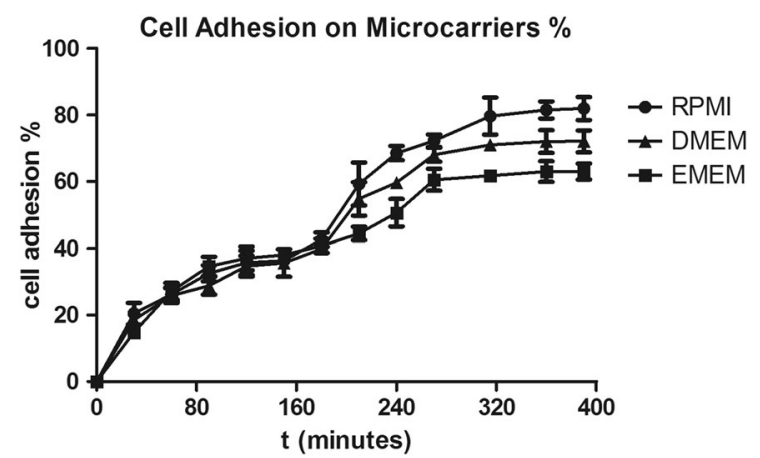

Fig. 3 The adhesion ratio percentage of HeLa cells on Cytodex 1 microcarriers using RPMI 1640, DMEM and EMEM media

also carried out during the cell incubation period. After the HeLa cells were incubated with Cytodex 1 in RPMI 1640, DMEM and EMEM media, the pH of each culture in Erlenmeyer flask was checked every $24 \mathrm{~h}$. The observed $\mathrm{pH}$ differences between the media were shown in Fig. 4. Based on these results, the lowest $\mathrm{pH}$ value at the end of the cultivation period 


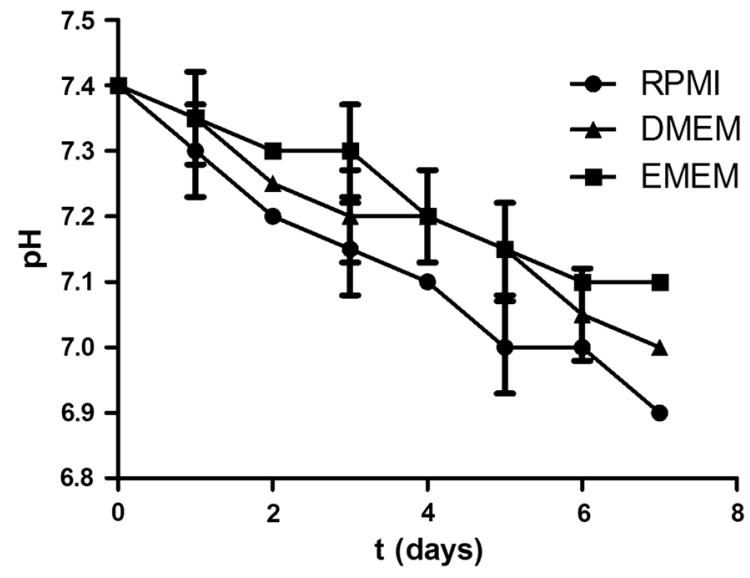

Fig. 4 The pH of the HeLa cell cultures in RPMI 1640, DMEM and EMEM media in Erlenmeyer flasks

was observed in HeLa cell culture incubated with RPMI medium (Fig. 4).

HeLa cells incubated with Cytodex 1 in RPMI 1640 medium using Erlenmeyer flasks reached $70-80 \%$ of confluence between the 3rd-4th days of culture. After 5th day, cells detached from the microcarriers due to lack of the nutrients in medium (Fig. 5a). HeLa cells incubated with Cytodex 1 in DMEM medium, the confluency was $60-70 \%$ between the 4 th and 5 th days of culture and thereafter cells detached from the microcarriers (Fig. 5b). HeLa cells incubated with Cytodex 1 in EMEM did not grow well in the estimated culture period (Fig. 5c).

SEM images showed that HeLa cells incubated with RPMI 1640 medium attached and grew on Cytodex 1 more intensely compared to the other two media (Fig. 5). Based on the results of the above mentioned experiments, RPMI 1640 was selected as the ideal medium to be used in "spinner flask bioreactors".

HeLa cell culture in spinner flasks

In this set of experiments, HeLa cells were adhered to Cytodex 1 in RPMI 1640 with two different concentrations $\left(1 \times 10^{5} \mathrm{cell} / \mathrm{ml}\right.$ and $\left.2 \times 10^{5} \mathrm{cell} / \mathrm{ml}\right)$. The $\mathrm{pH}$ alteration observed between two groups is shown in Fig. 6. The results showed that the $\mathrm{pH}$ decreased more abruptly in HeLa cell culture with $2 \times 10^{5}$ cell/ $\mathrm{ml}$ concentration.

Moreover, HeLa cells incubated with Cytodex 1 at $2 \times 10^{5}$ cells $/ \mathrm{ml}$ concentration attached more intensely to microcarriers as shown by SEM (Fig. 7b). HeLa cells incubated with Cytodex 1 at $2 \times 10^{5}$ cells/ $\mathrm{ml}$ concentration reached $80-90 \%$ confluency at the 3rd day of culture which is the ideal time for proliferation and addition of maintenance medium.

It was noted that the detachment time of HeLa cells from microcarriers extended to more than 7 days. On the other hand, HeLa cells incubated with Cytodex 1 at $1 \times 10^{5}$ cells $/ \mathrm{ml}$ concentration reached $70-80 \%$ confluency at 4th day of culture (Fig. 7a). Overall, $2 \times 10^{5} \mathrm{cell} / \mathrm{ml}$ was found to be more efficient inoculation concentration for the adhesion and growth of HeLa cells on Cytodex 1 microcarriers in spinner flasks.

T. gondii tachyzoites production on HeLa cell culture in spinner flask

T. gondii tachyzoites were inoculated to spinner flasks with 1:1 and 2:1 HeLa:tachyzoite ratio. The HeLa cell
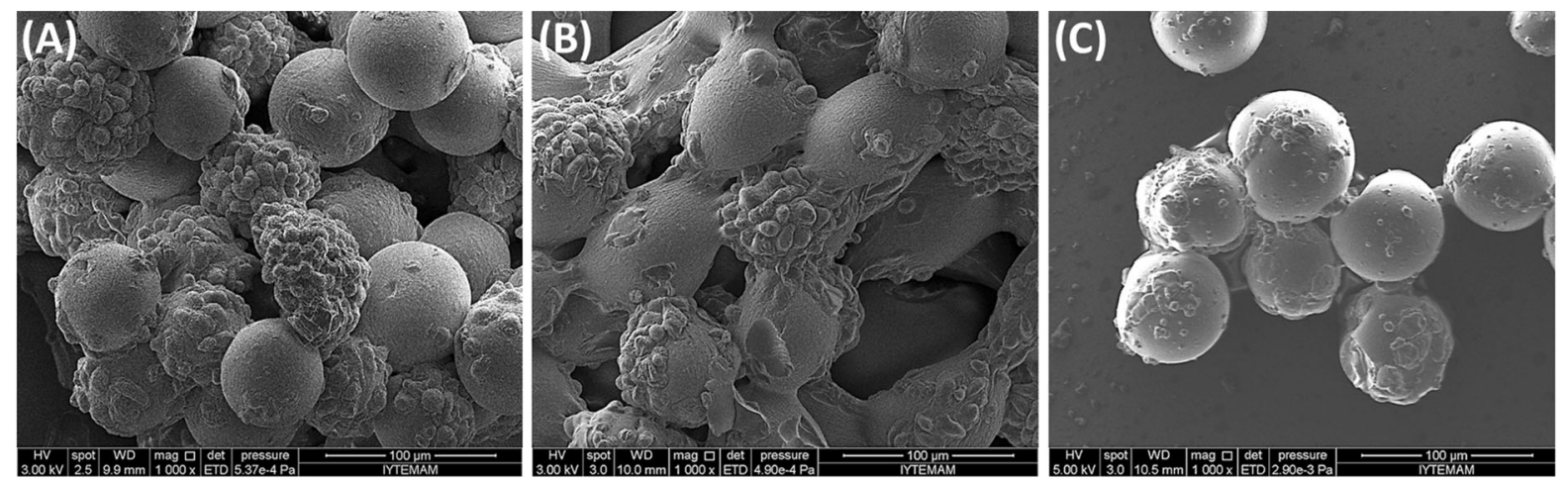

Fig. 5 SEM images of HeLa cells adhered on Cytodex 1 in a RPMI 1640, b DMEM and c EMEM media ( $\times 1000$, LEoL JSM-5200, Japan). The observed samples were taken from the 3 rd day of culture 


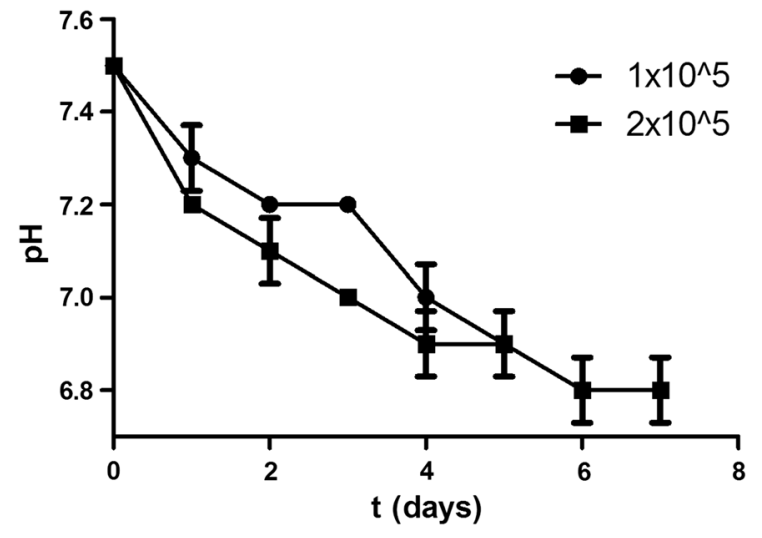

Fig. 6 The $\mathrm{pH}$ change of HeLa cell cultures in spinner flasks with two different concentrations $\left(1 \times 10^{5} \mathrm{cell} / \mathrm{ml}\right.$ and $2 \times 10^{5}$ cell $/ \mathrm{ml}$ )

concentration was $2 \times 10^{5}$ cell $/ \mathrm{ml}$ in a final volume of $200 \mathrm{ml}$ RPMI 1640 medium. Approximately $150 \mathrm{ml}$ of cell culture supernatants were collected after 2nd, 4th, and 7th days of culture. The amounts of viable tachyzoites and host cell ingredients are demonstrated in Table 1 . These results are obtained by concentrating $150 \mathrm{ml}$ of cell culture supernatant to $1 \mathrm{ml}$ as described in "Serological assays" section. According to the results, the amount of viable tachyzoites was the highest $\left(16.10 \times 10^{7} / \mathrm{ml}\right.$, viability rate: $\left.94.1 \%\right)$ and the host cell ingredient was $0.99 \times 10^{7} / \mathrm{ml}$ in the group with HeLa:tachyzoite ratio 1:1 harvested at the 4th day of culture. The least host cell ingredient was observed in the group with HeLa:tachyzoite ratio $2: 1$ harvested at the 2 nd day of culture $\left(0.43 \times 10^{7} / \mathrm{ml}\right)$ but the amount of viable tachyzoites was $4.07 \times 10^{7} /$
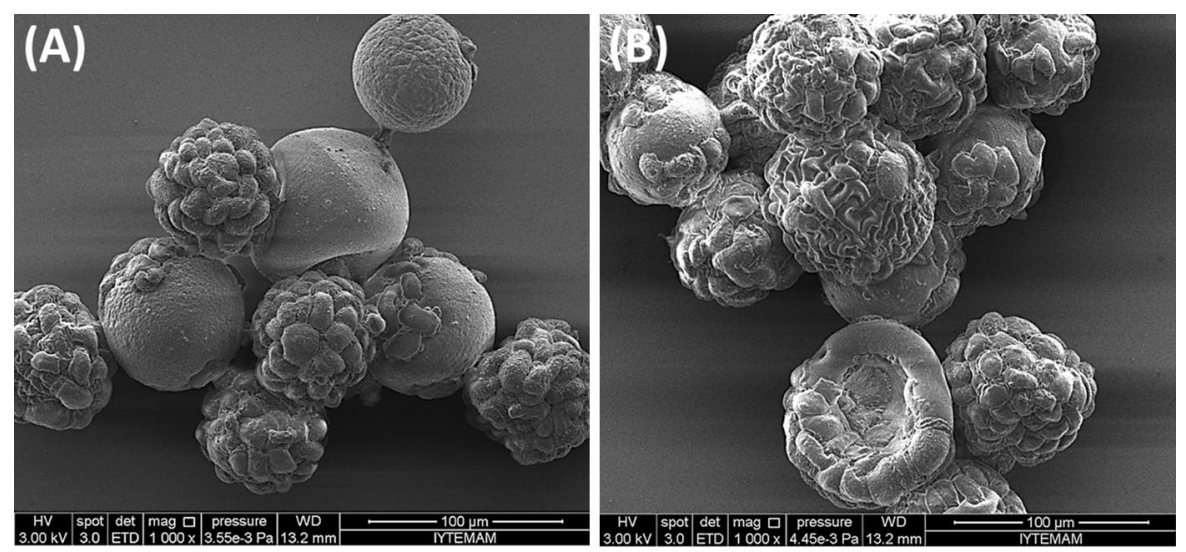

Fig. 7 SEM images of HeLa cells inoculated to Cytodex 1 at a $1 \times 10^{5}$ cells $/ \mathrm{ml}, \mathbf{b} 2 \times 10^{5}$ cells $/ \mathrm{ml}$ concentrations $(\times 1000$, LEoL JSM-5200, Japan). The observed samples were taken from the 3rd day of culture 
Table 1 The amount of tachyzoites and host cell ingredient observed in spinner flasks with 200 ml working volume

\begin{tabular}{lllccc}
\hline $\begin{array}{l}\text { Harvesting } \\
\text { day }\end{array}$ & $\begin{array}{l}\text { HeLa/tachyzoite } \\
\text { ratio }\end{array}$ & $\begin{array}{l}\text { Amount of viable } \\
\text { tachyzoites }\left(10^{7} / \mathrm{ml}\right)\end{array}$ & $\begin{array}{l}\text { Amount of total } \\
\text { tachyzoites }\left(10^{7} / \mathrm{ml}\right)\end{array}$ & $\begin{array}{l}\text { Viability rate } \\
(\%)\end{array}$ & $\begin{array}{l}\text { HeLa cell ingredient } \\
\left(10^{7} / \mathrm{ml}\right)\end{array}$ \\
\hline 2nd day & $1 / 1$ & 8.30 & 9.60 & 86.4 & 0.97 \\
& $2 / 1$ & 3.35 & 4.07 & 82.4 & 0.43 \\
4th day & $1 / 1$ & $\mathbf{1 6 . 1 0}$ & $\mathbf{1 7 . 1 0}$ & $\mathbf{9 4 . 1}$ & $\mathbf{0 . 9 9}$ \\
& $2 / 1$ & 7.50 & 8.32 & 90.1 & 0.92 \\
7 th day & $1 / 1$ & 9.15 & 10.07 & 90.8 & 3.45 \\
\end{tabular}

Bold ratios represent the harvest with the highest tachyzoite and highest viability rate accompanying with lowest HeLa cell ingredient

Table 2 The sensitivity and specificity of antigens obtained at 2nd, 4th, and 7 th days of culture

\begin{tabular}{|c|c|c|c|c|c|c|}
\hline & \multicolumn{2}{|c|}{ 2nd day (HeLa/tachyzoite) } & \multicolumn{2}{|c|}{ 4th day (HeLa/tachyzoite) } & \multicolumn{2}{|c|}{ 7th day $(\mathrm{HeLa} /$ tachyzoite $)$} \\
\hline & $2 / 1$ & $1 / 1$ & $2 / 1$ & $1 / 1$ & $2 / 1$ & $1 / 1$ \\
\hline Sensitivity (\%) & 91.4 & 91.4 & 88.6 & 100.0 & 97.1 & 97.1 \\
\hline Specificity (\%) & 75 & 75 & 100 & 100 & 100 & 100 \\
\hline
\end{tabular}

Bold values represent the HeLa derived antigen that has the highest sensitivity and specificity compared to mouse derived antigen

culture and mice had similar banding patterns. In HeLa cell culture derived antigens, the high molecular weight proteins were abundantly expressed compared to low molecular weight proteins (Fig. 9a). Moreover, the banding pattern intensity of the antigen obtained at 4th day of HeLa culture with 1:1 HeLa:tachyzoite ratio was similar to the antigen derived from mice (Fig. 9a, Lane 4 and Lane 7). On the other hand, the bands with molecular weights around $37 \mathrm{kDa}$ and $50 \mathrm{kDa}$ appeared in blots of positive and negative sera which are an indication of cross reaction (Fig. 9a, b).

\section{Discussion}

In serological diagnosis of toxoplasmosis, antigen quality is important to determine the humoral immune response against $T$. gondii infection. Thus, novel in vitro antigen production studies are required to obtain the highest antigen quality to be used as an alternative to antigen produced in animal models.

To detect IgG and IgM antibodies, lysate antigen or recombinant proteins are being used in ELISA and Western blotting. In addition, whole tachyzoites are used in IFA and dye tests. In our study, we aimed to develop a novel in vitro culture method which may allow abundant $T$. gondii tachyzoites production to be used as an antigen source in serological assays.

Before we produce $T$. gondii tachyzoites, several set of optimization experiments were performed. Initially, HeLa cells were grown with RPMI 1640, DMEM and EMEM media for determination of growth kinetic and cell adhesion time. According to these results, HeLa cells cultivated with RPMI 1640 had the highest viable cell concentration in exponential phase during growth kinetic and reached $100 \%$ of confluency at the 5th day of culture. Also, cell adhesion time was $180 \mathrm{~min}$ for this culture. Later, incubation of $3 \mathrm{~g} / \mathrm{l}$ of Cytodex 1 with $1 \times 10^{5} \mathrm{cell} / \mathrm{ml}$ HeLa cells in RPMI 1640 using single-use Erlenmeyer flasks resulted with $80-90 \%$ of confluency at the 3-4th days of culture.

In some studies, HeLa cells were grown in suspension without using microcarriers in Erlenmeyer flask at concentrations of $1.25 \times 10^{5}$ cells $/ \mathrm{ml}$ to produce the Coxsackie B3 Virus (Crowell and Syverton 1960) and $5 \times 10^{5}$ cells $/ \mathrm{ml}$ to isolate the Herpes virus (Armstrong, 1966). In another study, HeLa cells with concentrations of $1 \times 10^{5}$ cells $/ \mathrm{ml}$ and $1.5 \times 10^{5}$ cells $/ \mathrm{ml}$ were grown in suspension using Erlenmeyer flask and reached 90-97\% confluency at the 5th day of culture (Hellman et al. 1967). In one study, HeLa cells were initially adhered to glass beads at a concentration 

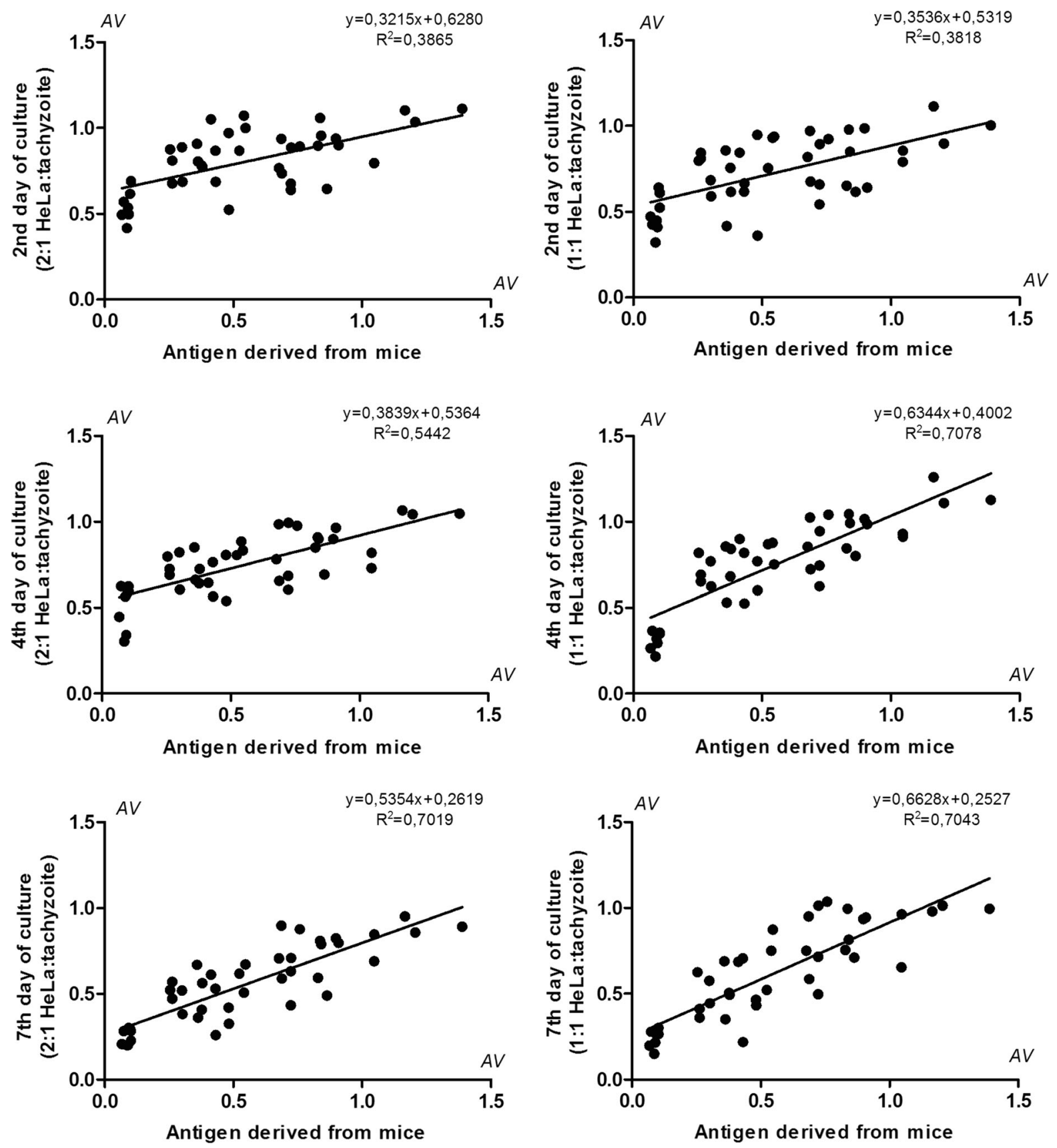

Fig. 8 Pearson correlation and linear regression analyses of ELISA absorbance values (AV) of antigens derived from three subsequent HeLa subcultures at 2nd, 4th, and 7 th days of culture

of $2 \times 10^{5}$ cells/ml and successfully grown in suspension using Erlenmeyer flasks (Blaker et al. 1971).

At the last step of our optimization, before the tachyzoite production, $3 \mathrm{~g} / \mathrm{l}$ of Cytodex 1 were incubated with $1 \times 10^{5} \mathrm{cell} / \mathrm{ml}$ or $2 \times 10^{5} \mathrm{cell} / \mathrm{ml}$

and Swiss Webster outbred mice. Cut-off value: the mean $\mathrm{AV}+\mathrm{S} . \mathrm{D}$. of the negative control sera

HeLa cells in RPMI 1640 using spinner flasks. The results showed that HeLa cells with concentration of $2 \times 10^{5}$ cells $/ \mathrm{ml}$ reached $80-90 \%$ of confluency in shorter time ( $3 \mathrm{rd}$ day of culture) compared to $1 \times 10^{5}$ cells $/ \mathrm{ml}$. 
(A) Positive pool

(B) Negative pool

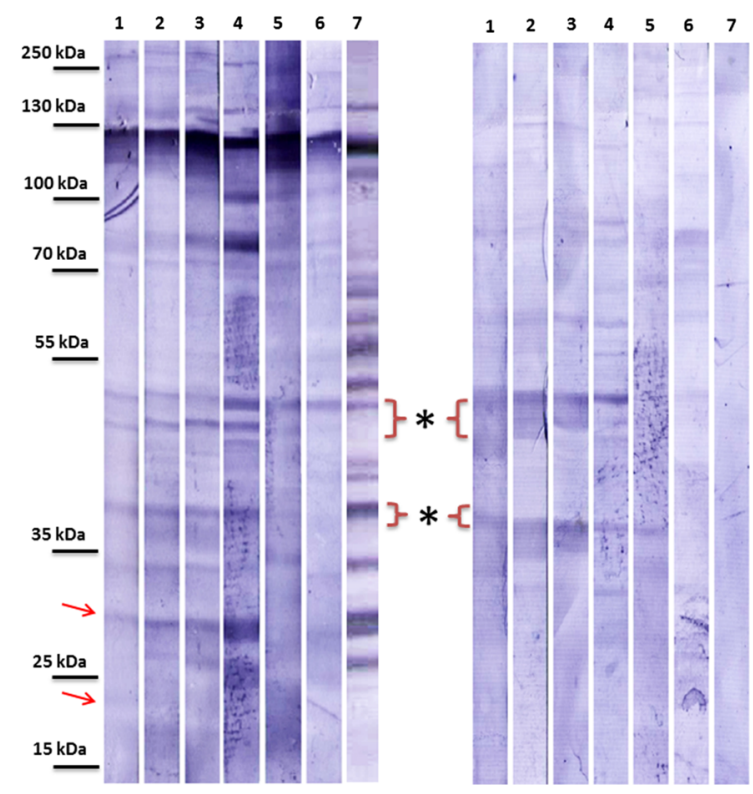

Fig. 9 The banding patterns observed by Western blotting. a Positive and b Negative serum sample pools. Lanes 1-3-5 HeLa cell culture derived antigens obtained at 2nd, 4th, and 7th days with 2:1 HeLa:tachyzoite ratio. Lanes 2-4-6 HeLa cell culture derived antigens obtained at $2 \mathrm{nd}$, 4th, and 7 th days with 1:1 HeLa:tachyzoite ratio. Lane 7 Mouse derived antigen. *Cross reactive bands, red arrows show the low molecular weight bands. (Color figure online)

It has been shown that the ideal host cell concentration to be used with Cytodex 1 microcarriers was between $5 \times 10^{4}$ cells $/ \mathrm{ml}-2 \times 10^{5}$ cells $/ \mathrm{ml}$. Among them, the optimum initial HeLa cell ratio to be used in spinner flask was determined as $2 \times 10^{5}$ cells $/ \mathrm{ml}$ (Boudreault et al. 2001; Souza et al. 2009; Fliedl and Kaisermayer, 2011; Kurokawa and Sato, 2011). Similar to our study, HeLa cell at concentration of $1 \times 10^{5}$ cells $/ \mathrm{ml}$ were adhered to $3,10,15$, and $25 \mathrm{~g} / \mathrm{l}$ of Cytodex 3 in DMEM using spinner flasks and reached nearly $100 \%$ confluency between 6 th and 7 th day of culture (Bleckwenn et al. 2005). The time difference associated with confluency may be related to the medium used since we reached $80-90 \%$ confluence between the 3 rd-4th days and $100 \%$ confluency at the 5th day of culture using RPMI1640 medium.

In the present study, our final aim was to develop a novel in vitro culture method to produce $T$. gondii tachyzoites in HeLa cells adhered to Cytodex 1 microcarriers. As the growth of HeLa cells on Cytodex 1 has been optimized in spinner flasks and the confluency reached 80-90\%, tachyzoites were inoculated to spinner flasks at 1:1 and 2:1 cell:tachyzoite ratios. Thereafter, viable tachyzoite yields were calculated in cell culture supernatants collected after 2nd, 4th, and 7th days of culture. According to the results, the highest viable tachyzoite production $\left(16.1 \times 10^{7} /\right.$ $\mathrm{ml}$ ) with accompanying low HeLa cell ingredient $\left(0.99 \times 10^{7} / \mathrm{ml}\right)$ was obtained at 4 th day of culture with 1:1 cell:tachyzoite ratio (Table 1).

Previously, Chatterton et al. (2002) cultured HeLa cells with EMEM medium in $75-\mathrm{cm}^{2}$ flasks to produce the $T$. gondii tachyzoites. In that study, tachyzoites were inoculated to HeLa cells with $1: 1$ cell:tachyzoite ratio as the HeLa cells reached $80-90 \%$ confluency. The results showed that tachyzoite yield was $1 \times 10^{6} \%$ $\mathrm{ml}$ and viability was $>90 \%$ between the 2 nd-6th days of culture (Chatterton et al. 2002). In another study, $T$. gondii tachyzoites were inoculated to HeLa cells with 1:1 cell:tachyzoite ratio using RPMI 1640 medium and the highest amount of tachyzoites were obtained at the 3rd day of culture (Wu et al. 2011).

In our group's previous study, $T$. gondii tachyzoites were inoculated to HeLa cells with 2:1, 1:1, 1:2 and 1:8 cell:tachyzoite ratios. The highest viable tachyzoite production $\left(5 \times 10^{6} / \mathrm{ml}\right)$ with accompanying HeLa cell ingredient $\left(1.16 \times 10^{6} / \mathrm{ml}\right)$ was obtained from 3rd day of culture with 2:1 cell:tachyzoite ratio. In addition, the highest tachyzoite yield $\left(3 \times 10^{6} / \mathrm{ml}\right)$ with lowest host ingredient $\left(0.12 \times 10^{6} / \mathrm{ml}\right)$ was observed at the 2 nd day of culture with $1: 8$ cell:tachyzoite ratio. The ratio of viable tachyzoite:host cell ingredient was $25\left(3 \times 10^{6} / \mathrm{ml}: 0.12 \times 10^{6} / \mathrm{ml}\right)$ at the 2nd day of culture with 1:8 cell:tachyzoite ratio. In addition, the highest tachyzoite yield was obtained from 3rd day of culture with 2:1 cell:tachyzoite ratio in which the ratio of viable tachyzoite:host cell ingredient was $4.3\left(5 \times 10^{6} / \mathrm{ml}: 1.16 \times 10^{6} / \mathrm{ml}\right)($ Değirmenci et al. 2011). In our study, the ratio of viable tachyzoite:host cell ingredient is $16.26\left(16.1 \times 10^{7} /\right.$ $\left.\mathrm{ml}: 0.99 \times 10^{7} / \mathrm{ml}\right)$ using Cytodex 1 microcarriers in spinner flasks. Accordingly, production of T. gondii tachyzoites using HeLa cells adhered to Cytodex 1 in spinner flasks appears to be a more practical method to reach higher tachyzoite yield.

After T. gondii tachyzoite production was performed in different cell lines, the antigen quality has generally been tested by various serological tests such as ELISA, Western blotting, and Sabin Feldman dye 
test (Chatterton et al. 2002; Değirmenci et al. 2011; da Costa-Silva et al. 2012).

In our study, we compared the six antigens by ELISA and Western blotting. The accumulated data suggests that the antigen obtained at 4th day of HeLa culture with 1:1 HeLa:tachyzoite ratio was similar to the antigen derived from mice (Table 2; Figs. 8, 9) based on the sensitivity $(100 \%)$ and specificity $(100 \%)$, correlation coefficient giving positive linear relation as well as banding patterns.

In our previous study, the quality of antigens was tested with IFA, ELISA, and Western blotting. Based on the results the specificity (90-100\%) and sensitivity $(100 \%)$ of the antigen harvested from the first passage of HeLa cell culture performed at 2 day intervals were comparable to the antigen harvested from mice (Değirmenci et al. 2011). In another study, antigens derived from HeLa cells culture with 1:1 cell:tachyzoite ratio were analysed to detect the antigen quality by Sabin Feldman dye test. According to these result, Sabin Feldman dye test success was between 77.5 and 93.5\% (Chatterton et al. 2002). Using an antigen derived from Vero cell culture which had approximately 1:1 cell:tachyzoite ratio, the sensitivity and specificity of ELISA were 100\% (da Costa-Silva et al. 2012).

Western blotting is a useful assay to determine the presence of anti-Toxoplasma antibodies. It has been showed that low molecular weight bands $6,20,22,23$, 25 , and $36 \mathrm{kDa}$ were valuable in the diagnosis of toxoplasmosis. Also, it is reported that 20,30 and $37 \mathrm{kDa}$ molecular weight bands were typical for $T$. gondii (Contini et al. 1998; Robert-Gangneux et al. 2000; Gallego-Marín et al. 2006; Remington et al. 2004; Franck et al. 2008). In this study, banding pattern of the antigen obtained at the 4th day of HeLa culture with 1:1 HeLa:tachyzoite ratio was similar to the antigen derived from mice and typical low molecular weight bands with a molecular weight of 20 and $30 \mathrm{kDa}$ were observed. The non-specific bands that appear on both the negative and positive controls may be due to host cell ingredient and remnants of cell culture medium.

The results of our in vitro cell culture studies showed that the antigen obtained at 4th day of HeLa culture with 1:1 HeLa:tachyzoite ratio gave the highest amount of total and viable tachyzoites with the least amount of HeLa cells ingredient. Besides, the results of ELISA (Quantitative) and Western blotting
(Qualitative) displayed that the best antigen for diagnostic purposes was obtained from the 4th day of culture with 1:1 cell:tachyzoite ratio.

\section{Conclusion}

Overall, our achievement of pilot scale production of tachyzoites using microcarriers in spinner flasks and successful usage of tachyzoites as antigen in serological assays showed that large scale production of $T$. gondii using microcarriers in bioreactors is feasible and tachyzoites produced by this method can be used as antigen in serological assays with high sensitivity and specificity in future. In addition, although this method does not completely ameliorate the ethical problems, it enables decrease in animal use for antigen production and solves the economic problems.

Acknowledgements This study was supported by the grant given by the Scientific Research Projects Branch Directorate of Ege University, Turkey (Grant No: 2014-TIP-042) to M.D. In addition, access to the Animal Cell \& Tissue Engineering laboratories of Ege University, Department of Bioengineering are highly appreciated.

\section{Compliance with ethical standards}

Conflict of interest The authors declare that they have no conflict of interest.

\section{References}

Armstrong D (1966) Serial cultivation of human leukemic cells. Proc Soc Exp Biol Med 122:475-481

Ashburn D, Evans R, Chatterton JM, Joss AW, Ho-Yen DO (2000) Toxoplasma dye test using cell culture derived tachyzoites. J Clin Pathol 53:630-633

Ashburn D, Chatterton JM, Evans R, Joss AW, Ho-Yen DO (2001) Success in the toxoplasma dye test. J Infect 42:16-19

Ayyildiz-Tamis D, Avcı K, Deliloglu-Gurhan SI (2014) Comparative investigation of the use of various commercial microcarriers as a substrate for culturing mammalian cells. In Vitro Cell Dev Biol Anim 50:221-231

Blaker GJ, Birch JR, Pirt SJ (1971) The glucose, insulin and glutamine requirements of suspension cultures of HeLa cells in a defined culture medium. J Cell Sci 9:529-537

Bleckwenn NA, Bentley WE, Shiloach J (2005) Evaluation of production parameters with the vaccinia virus expression system using microcarrier attached HeLa cells. Biotechnol Prog 21:554-561

Boudreault P, Tremblay JP, Pépin MF, Garnier A (2001) Scaleup of a myoblast culture process. J Biotechnol 91:63-74 
Buddhirongawatr R, Tungsudjai S, Chaichoune K, Sangloung C, Tantawiwattananon N, Phonaknguen R, Sukthana Y (2006) Detection of Toxolasma gondii in captive wild felids. Southeast Asian J Trop Med Public Health 37:15-17

Butler M (2005) Animal cell cultures: recent achievements and perspectives in the production of biopharmaceuticals. Appl Microbiol Biotechnol 68:283-291

Chatterton JM, Evans R, Ashburn D, Joss AW, Ho-Yen DO (2002) Toxoplasma gondii in vitro culture for experimentation. J Microbiol Methods 51:331-335

Chen AK, Reuveny S, Oh SK (2013) Application of human mesenchymal and pluripotent stem cell microcarrier cultures in cellular therapy: achievements and future direction. Biotechnol Adv 31:1032-1046

Contini C, Fainardi E, Cultrera R, Canipari R, Peyron F, Delia S, Paolino E, Granieri E (1998) Advanced laboratory techniques for diagnosing Toxoplasma gondii encephalitis in AIDS patients: significance of intrathecal production and comparison with PCR and ECL-western blotting. J Neuroimmunol 92:29-37

Crowell RL, Syverton JT (1960) The mammalian cell-virus relationship VI. sustained infection of HeLa cells by coxsackie B3 virus and effect on superinfection. J Exp Med 113:419-435

da Costa-Silva TA, da Silva MC, Frazzatti-Gallina N, PereiraChioccola VL (2012) Toxoplasma gondii antigens: recovery analysis of tachyzoites cultivated in Vero cell maintained in serum free medium. Exp Parasitol 130:463-469

Değirmenci A, Döşkaya M, Caner A, Ciçek C, Korkmaz M, Gürüz Y, Uner A (2011) Toxoplasma gondii RH Ankara: production of evolving tachyzoites using a novel cell culture method. Exp Parasitol 128:1-8

Diab MR, El-Bahy MM (2008) Toxoplasma gondii: virulence of tachyzoites in serum free media at different temperatures. Exp Parasitol 118:75-79

Döşkaya M, Degirmenci A, Ciçek C, Ak M, Korkmaz M, Gürüz Y, Uner A (2006) Behaviour of Toxoplasma gondii RH Ankara strain tachyzoites during continuous production in various cell lines. Parasitology 132:315-319

Döşkaya M, Caner A, Can H, Gülce İz S, Değirmenci A, Gürüz Y (2013) Cryopreservation of Toxoplasma gondii tachyzoites and tissue cysts. Turk J Parasitol 37:44-46

Döşkaya M, Caner A, Can H, Gülçe İz S, Gedik Y, Değirmenci Döşkaya A, Kalantari-Dehaghi M, Gürüz Y (2014) Diagnostic value of a Rec-ELISA using Toxoplasma gondii recombinant SporoSAG, BAG1, and GRA1 proteins in murine models infected orally with tissue cysts and oocysts. PLoS ONE 9:e108329

Evans R, Chatterton JM, Ashburn D, Joss AW, Ho-Yen DO (1999) Cell culture system for continuous production of Toxoplasma gondii tachyzoites. Eur J Clin Microbiol Infect Dis 18:879-884

Fliedl L, Kaisermayer C (2011) Transient gene expression in HEK293 and Vero cells immobilised on microcarriers. J Biotechnol 153:15-21

Francis JM, Payne RA, Joynson DHM (1988) Rapid indirect enzyme-linked immunosorbent assay (ELISA) for detecting antitoxoplasma IgG: comparison with the dye test. J Clin Pathol 41:802-805

Franck J, Garin YJ, Dumon H (2008) LDBio-Toxo II immunoglobulin G Western blot confirmatory test for anti- toxoplasma antibody detection. $\mathrm{J}$ Clin Microbiol 46:2334-2338

Freshney RI (2010) Culture of animal cells, 6th edn. Wiley, London

Fritz H, Barr B, Packham A, Melli A, Conrad PA (2012) Methods to produce and safely work with large numbers of Toxoplasma gondii oocysts and bradyzoite cysts. J Microbiol Methods 88:47-52

Gallego-Marín C, Henao AC, Gómez-Marín JE (2006) Clinical validation of a western blot assay for congenital toxoplasmosis and newborn screening in a hospital in Armenia (Quindio) Colombia. J Trop Pediatr 52:107-112

Gürhan Sİ, Ünal N, Kiremitçi M (1994) Relationship of inactivation techniques of the sera to cellular attachment on PHEMA and polypropylene surfaces. Anim Cell Technol Basic Appl Asp 6:389-394

Gürüz AY, Ok UZ, Korkmaz M (1996) Assessment of latex indirect agglutination test (Toxolatex Fumouze) for the detection of toxoplasma specific antibodies in human sera in Turkey. J Egypt Soc Parasitol 26:367-374

Hellman A, Regan JD, Martin DH (1967) Large-scale cultivation of mammalian cells in vitro. Appl Microbiol 15:201-202

Ho-Yen DO (2010) Annual reports, 2005-2009, Scottish Toxoplasma Reference Laboratory. http://www.hps.scot.nhs. uk/reflab/RefLabDetail.aspx?id=21. Active 2 Aug 2010

Jakob PH, Kehrer J, Flood P, Wiegel C, Haselmann U, Meissner M, Stelzer EH, Reynaud EG (2016) A 3-D cell culture system to study epithelia functions using microcarriers. Cytotechnology 68:1813-1825

Kahraman E, Deliloğlu Gürhan İ, Korkmaz M (2013) Investigation of the potential cytotoxic and genotoxic effects of different boron compounds on the CCL 62 (HeLa contaminant) human amniotic epithelial cell lines. Med Sci 2:454-468

Kato D, Takeuchi M, Sakurai T, Furukawa S, Mizokami H, Sakata M, Hirayama C, Kunitake M (2003) The design of polymer microcarrier surfaces for enhanced cell growth. Biomaterials 24:4253-4264

Koethe M, Straubinger RK, Pott S, Bangoura B, Geuthner AC, Daugschies A, Ludewig M (2015) Quantitative detection of Toxoplasma gondii in tissues of experimentally infected turkeys and in retail turkey products by magnetic-capture PCR. Food Microbiol 52:11-17

Kurokawa M, Sato S (2011) Growth and poliovirus production of Vero cells on a novel microcarrier with artificial cell adhesive protein under serum-free conditions. J Biosci Bioeng 111:600-604

Liang L, Döşkaya M, Juarez S, Caner A, Jasinskas A, Tan X, Hajagos BE, Bradley PJ, Korkmaz M, Gürüz Y, Felgner PL, Davies DH (2011) Identification of potential serodiagnostic and subunit vaccine antigens by antibody profiling of toxoplasmosis cases in Turkey. Mol Cell Proteom 10:M110.006916

Masatani T, Takashima Y, Takasu M, Matsuu A, Amaya T (2016) Prevalence of anti-Toxoplasma gondii antibody in domestic horses in Japan. Parasitol Int 65:146-150

Merten OW (2015) Advances in cell culture: anchorage dependence. Philos Trans R Soc Lond B Biol Sci 370:20140040 
Microcarrier Cell Culture Prenciples \& Methods (2005) http:// www.gelifesciences.com. Accessed 13 Dec 2016

Oyeleye OO, Ogundeji ST, Ola SI, Omitogun OG (2016) Basics of animal cell culture: foundation for modern science. Biotechnol Mol Biol Rev 11:6-16

Payne RA, Joynson DH, Balfour AH, Harford JP, Fleck DG, Mythen M, Saunders RJ (1987) Public health laboratory service enzyme linked immunosorbent assay for detecting Toxoplasma specific IgM antibody. J Clin Pathol 40:276-281

Remington JS, Thulliez P, Montoya JG (2004) Recent developments for diagnosis of toxoplasmosis. J Clin Microbiol 42:941-945

Robert-Gangneux F, Amrein C, Lavarde V, Botterel F, DupouyCamet J (2000) Neosynthesized IgG detected by western blotting in Toxoplasma-seropositive heart or lung transplant recipients. Transpl Int 13:448-452

Rourou S, van der Ark A, van der Velden T, Kallel H (2007) A microcarrier cell culture process for propagating rabies virus in Vero cells grown in a stirred bioreactor under fully animal component free conditions. Vaccine 25:3879-3889
Souza MC, Freire MS, Schulze EA, Gaspar LP, Castilho LR (2009) Production of yellow fever virus in microcarrierbased Vero cell cultures. Vaccine 27:6420-6423

Sun LY, Lin SZ, Li YS, Harn HJ, Chiou TW (2011) Functional cells cultured on microcarriers for use in regenerative medicine research. Cell Transpl 20:49-62

Toulah FH, Sayed Al-Ahl SA, Amin DM, Hamouda MH (2011) Toxoplasma gondii: ultrastructure study of the entry of tachyzoites into mammalian cells. Saudi J Biol Sci 18:151-156

van Wezel AL (1967) Growth of cell-strains and primary cells on micro-carriers in homogeneous culture. Nature 216:64-65

Wu SC, Liu CC, Lian WC (2004) Optimization of microcarrier cell culture process for the inactivated enterovirus type 71 vaccine development. Vaccine 22:3858-3864

Wu L, Chen SX, Jiang XG, Fu XL, Shen YJ, Cao JP (2011) Separation and purification of Toxoplasma gondii tachyzoites from in vitro and in vivo culture systems. Exp Parasitol 130:91-94 